that Council had seen my letters and that 'as supreme governing body, the College Council has the full management and control of the College and of its affairs'. The matter was closed when Dr Birley, the next President, wrote that 'the procedure concerning the Council's resolution was that followed by our Council in the conduct of its affairs. It does not require a plebiscite of its members. The resolution may not be so draconian as you feared'. So Dr Birley justified Council procedure, its disposing of a major policy decision at an ordinary business meeting attended by 80 members, and confirms that Council had imposed 'draconian' restrictions on South Africa without publishing a reason. Surely this is a confession of the abuse of psychiatry, and of the authority of a president, for political motives?

The resolution was put into effect when Professor Simpson, a South African member, was banned from giving his paper on 'AIDS in Africa' at the Autumn Quarterly Meeting. Dr Birley told the press that members had threatened violence otherwise, and that the decision was 'political'. ${ }^{4}$ Who were these members? What action has been taken against them? However, a proposal for the British Psychological Society to follow the College resolution was ruled ultra vires the Royal Charter ${ }^{5}$ by their Honorary General Secretary. I am a British subject, now resident and working in South Africa. I do not have the right to vote. I condemn utterly the resolution of the College, of which I am a Foundation Fellow, intended to hinder my work and teaching. The position of Fellows in South Africa in relation to other doctors and the Government may now be invidious because of the policy of the College.

For this reason I published a factual account of the affair in the South African Medical Journal. ${ }^{6}$ As it may not be seen by members, I am now informing them in the Bulletin. The resolution is obviously ultra vires and its content incorrect. It should be rescinded. But the motivation for the resolution raises very serious questions. Although it is unethical, Council has said it had been approved by the British and Commonwealth Governments. Members are permitted to have professional relationships with South Africans, only if they serve Council's political aims. The resolution was passed without the consent or even the knowledge of $98 \%$ of Members.

There can be no confidence in the administration of the College until this irregular and confusing affair has been fully cleared up.

Groote Schuur Hospital,

Cape Town, South Africa

REFERENCES

${ }^{1}$ Council Resolution on Apartheid (1987) Bulletin of the Royal College of Psychiatrists, 11, 246.

${ }^{2}$ Royal College of Psychiatrists (1987) Quarterly Business Meeting, 28 January 1987 (no. 4)

${ }^{3}$ BewLEY, T. (1987) Appeal for Research Unit (Letter inserted in June 1987 issue). Bulletin of the Royal College of Psychiatrists, 11.
${ }^{4}$ Thompson, G. (1987) Stiffling a cry for freedom. The Argus, 9 November 1987.

${ }^{5}$ THE EDTTOR's Note (1987) The Bulletin of the British Psychological Society, 40, 379.

${ }^{6}$ Hemphill, R. E. (1987) The Royal College of Psychiatrists and medical sanctions against South Africa. South African Medical Journal, 72, 659-660.

Dr Birley replies

To take Dr Hemphill's points in order:

(1) The adoption of the resolution was announced in the Bulletin in March 1987 and guidelines were published in the July 1987 edition. The correct procedures were followed and no secrecy was involved.

(2) The text of the resolution is that published by the Commonwealth Secretariat in the book Mission to South Africa (1986). This followed the visit of 'eminent persons' to South Africa. Lord Barber was the British representative. The Prime Minister referred, with approval, to the Nassau Accord on her recent visit to Kenya and Nigeria.

(3) Our action is not ultra vires. The College has commented on other situations, notably concerning the abuse of psychiatry in Russia. We were also accused then, by the Russians, of political interference.

(4) Dr Hemphill refers to 'a boycott'. Council guidelines indicate clearly that no boycott is intended. I have already written in the Bulletin (February 1988 and below) and elsewhere concerning the matter of Professor Simpson. No members had ever threatened violence on this matter, nor did I ever say they had done so.

DR J. L. T. BIRLEY President

\section{Professor Simpson writes}

DEAR SIRS

I am writing to place on record an episode of disgraceful behaviour on the part of the College in October 1987. Having been denied academic freedom in this country, I did not expect a more stringent denial of my professional rights by my own College, in Britain.

Let me summarise what happened. I was invited, as the College's guest, to speak at the Autumn meeting, in a symposium on AIDS. I later submitted a short paper on a vitally important and sensitive psychiatric topic, which was accepted for presentation at the meeting. I have been a distinguished academic psychiatrist in Britain, Canada and America; a member of the College for some 15 years, a previous Examiner for the College.

After I came to South Africa, to this area of such great need, I suffered great persecution and personal harassment because of my opposition to apartheid, my work with black students and community groups, and my work in establishing that harsh political detentions without trial caused psychiatric damage, amongst other work. I was eventually forced out of my senior academic post by continuous harassment, including death threats.

In both of my invited addresses to the College meeting 